\title{
Analytical study of the causes of the major landslide of Bukit Antarabangsa in 2008 using fault tree analysis
}

\author{
Danish Kazmi $^{1}$ - Sadaf Qasim ${ }^{1}$ - I. S. H. Harahap ${ }^{2}$ Thu Hang Vu ${ }^{3}$
}

Received: 26 July 2017 / Accepted: 25 September 2017 / Published online: 10 October 2017

(C) Springer International Publishing AG 2017

\begin{abstract}
Previous researchers have observed that imprecise design, flawed construction and non-maintenance of slopes are major contributors to Malaysian landslides. The prominent landslide of Bukit Antarabangsa in 2008 once again alarmed the Malaysian construction industry and prompted a review of their practices and standards. This study investigates the causes of the Bukit Antarabangsa landslide by analyzing a pipe burst event, which according to previous studies triggered the landslide. The technique of fault tree analysis (FTA) is applied to trace factors contributing to the pipe burst. The events and their subjective probability for the FTA have been ascertained by experts in the Malaysian construction industry through survey research using a snowball sampling technique. Subjective probability derived for FTA indicates that high acidity levels in the water, improper design and a temporary extra surcharge load were more likely to be causal factors than other potential triggers. The events that are found to have the highest subjective probability in causing the pipe burst correlate with
\end{abstract}

Danish Kazmi

danish.kazmi@hotmail.com

Sadaf Qasim

sadafqasim26@yahoo.com

I. S. H. Harahap

indrasati@petronas.com.my

Thu Hang Vu

h.vu@ecu.edu.au

1 Department of Civil Engineering, NED University of Engineering and Technology, Karachi 75270, Pakistan

2 Department of Civil and Environmental Engineering, Universiti Teknologi Petronas, 32610 Perak, Malaysia

3 School of Engineering, Edith Cowan University, Joondalup 6027, Australia human errors which occur either as a result of negligence or as a result of several types of uncertainties. In this context, this study suggests a theoretical framework to address human errors and to mitigate the chances of slope failure.

Keywords Bukit Antarabangsa - Pipe burst event · Fault tree analysis $\cdot$ Snowball sampling $\cdot$ Human errors $\cdot$ Slope failure

\section{Introduction}

Landslides are one of the major geohazards occurring frequently in Malaysia. They are responsible for both compensatory and non-compensatory losses. Besides damaging infrastructure, they cause loss of life, environmental degradation, and interrupt the economic activity. In Bukit Antarabangsa in 2008, a landslide damaged the settlements and resulted in casualties [1]. Altogether this landslide caused five casualties, buried fourteen bungalows, and forced approximately 2000 residents to evacuate their homes [2].

In most landslide studies, the primary focus is toward the technical perspectives of failure, and human errors are neglected. Authorities have already established that no signs of earth motion were evident in seismic records, so the possibility that the 2008 landslide was triggered by earthquake forces is negligible. Another possibility which has been highlighted is that this landslide was the outcome of a pipe burst [3]. The official authority of Majlis Perbandaran Ampang Jaya (MPAJ) at Ulu Klang, Malaysia reported on the 2008 Bukit Antarabangsa landslide, identifying leaking water pipelines near Jalan Wangsa 11, which is very close to the landslide area, being responsible for the buildup of water pressure in the soil pores. Harahap and Aini [4] observed that the landslide took place after 20 years of 
project development, and it is thought to have been the result of a water pipe burst on the hill.

This study aims to identify the causes of the pipe burst event which potentially led to the slope failure and the subsequent landslide in Bukit Antarabangsa. If this landslide was attributed only to technical causes, then this is not the complete picture, because the previous record of Malaysian landslides proves that human-generated design and construction errors play a significant role in these types of events. The issues related to improper drainage in the slope and a lack of adequate maintenance are fairly common and human errors must be analyzed alongside technical causes to comprehensively evaluate this landslide event.

In principle, there are many factors that may stimulate pipe failure including environmental and external conditions (soil moisture and air temperature), structural and physical variables (pipe length, pipe diameter and material), internal factors (water quality and water temperature) and maintenance variables (number of leakages, number of repairs and number of failures). The aging of pipes also contributes to failure as it affects the material properties and obstructs the water flow. Røstum [5] indicated that nearby excavation around the bedding area of the pipes is another triggering factor, as it disturbs the layout of the pipe. A list of important factors affecting the quality of the pipe is given in Table 1.

\section{Literature review}

See-Sew and Tan [6] investigated the causes of landslides in Malaysia over a period of 6 years and reported that 43 out of a total 49 landslide cases were the result of design and construction errors. Jabatan Kerja Raya (JKR), which is a federal government department in Malaysia, also confirmed that most of the landslides in Malaysia are primarily caused by design and construction errors, as shown in Fig. 1. Some of the common flaws leading to slope failure are as follows:
Landslides Statistics

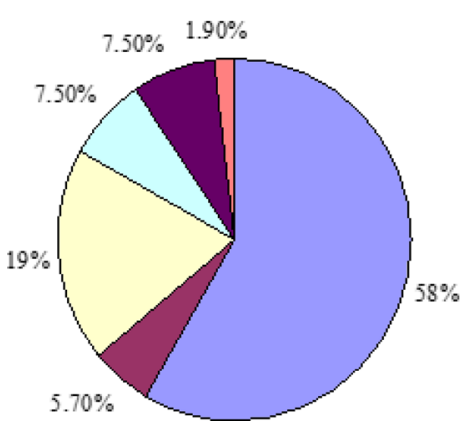

Fig. 1 Landslides statistics of Malaysia [7]

1. abuse of prescriptive methods in terms of gradient $1 \mathrm{H}: 1 \mathrm{~V}$,

2. increasing the number of berms without considering the effects on slope safety factors,

3. insufficient laboratory test results,

4. lack of adequate drainage facility.

Proactive approaches are often used to analyze the uncertainties associated with slopes. For example, probabilistic reliability assessment (PRA), which relies on uncertainties related to inherent factors, is used to estimate the likelihood of failure. In addition to PRA, there are other established approaches that are used to determine safety factors, load factors and resistance factors.

Peck [8] proposed an observational method to deal with uncertainties, but the feasibility of this method is limited to situations where design can be altered and performed over conservative values of load and material properties, which may not be suitable for all geotechnical structures. During the past few years, attention has been diverted toward reliability analysis as a way to deal effectively with uncertainties. Nadim [9] discussed two basic categories of uncertainties:

Table 1 Factors affecting water pipes [5]

\begin{tabular}{llll}
\hline Structural variables & Environmental variables & Internal variables & Maintenance variables \\
\hline Location & Soil nature & Water quality & Failure location \\
Diameter & Loading & Water pressure & Failure date \\
Length & Groundwater & Water hammer & Repair date \\
Year of construction & Leakage rate & Internal corrosion & Failure type \\
Wall thickness & Direct stray current & & Failure history \\
Laying depth & Temperature & & \\
Pipe material & External corrosion & & \\
Internal protection & Bedding condition & & \\
External protection & Salt for deicing of roads & & \\
Joint method & Other networks & & \\
Pressure level & & & \\
\hline
\end{tabular}


1. inherent uncertainty, which shows the natural randomness of any variable;

2. epistemic uncertainty, which demonstrates measurement, statistical and model uncertainties.

The reliability index, which is a measure of safety, is another parameter which can be estimated by putting reliability theory into practice. The parameters that influence the reliability index can be easily computed using sensitivity analysis, but the effects of human error are not considered. This raises the question of how useful human reliability is and what could be its impact on minimizing the chances of failure.

Whitman [10] discussed the reasons why predicted failure rates are generally underestimated and actual failure rates are higher than the predicted. A key reason is human error, including the violation of specifications and ignoring guidelines, which ultimately increase human error probabilities (HEPs). Nearly all systems interact with humans during the planning, designing, construction and installation stages. Thus, human errors, which may be either knowledge based or behavior based, can be compounded. This study presents a classification of human errors by categorizing them into knowledge-based and behaviour-based errors, as shown in Fig. 2.

Sowers [11] discovered that among 500 well-known cases of foundation failure, $88 \%$ were due to human errors and the remaining $12 \%$ were due to technological issues. The causes of the major accidents have also been found to be human oriented. It is suggested that nearly $80 \%$ of accidents involve human, organizational and knowledge uncertainties. A general discussion of human errors has been conducted by Bea [12]. Furthermore, Kazmi et al. [13] concluded that human errors play a dominant role in triggering landslides in Malaysia.

Following studies on the human causes of failure, it is now becoming evident that the reliability of a structure is not only technology dependent, but is also affected by the quality of design. Construction methods and maintenance must also meet the specifications. In terms of slope stabilization, the decision to select an appropriate method requires a thorough evaluation of the existing slope conditions and assessment of the causes that are responsible for the instability [14].

At approximately 3.30 am on 6 December 2008, a landslide occurred at Taman Bukit Mewah, Bukit Antarabangsa, Hulu Kelang, Selangor, Malaysia. The landslide was $109 \mathrm{~m}$ wide at the crest, $120 \mathrm{~m}$ long and $15 \mathrm{~m}$ deep, and the angle of the scarp at the crown was approximately $45^{\circ}-50^{\circ}$. It was estimated that $101-500 \mathrm{~m}^{3}$ of earth moved and the maximum run-out distance of the failure debris was approximately $210 \mathrm{~m}$ from the toe of the slope [15].

Seismic records obtained from the Malaysian Meteorological Department show that there was no sign of earthquake motion on the day of the Bukit Antarabangsa 2008 landslide or during the month before. This eliminates earthquake as a probable cause of failure [15].

With regard to the mechanism of landslide activation, Huat et al. [15] concluded that, in combination with other contributing factors, a heavily leaking active water pipe alongside abandoned houses may have triggered the landslide due to high pore water pressure at the toe of the slope, as no rain was recorded over several days before the failure. Nanak and Harahap [2] also reported that leakages from the active water pipe across the slope to an adjacent abandoned house, which led to an increase in pore water pressure in the

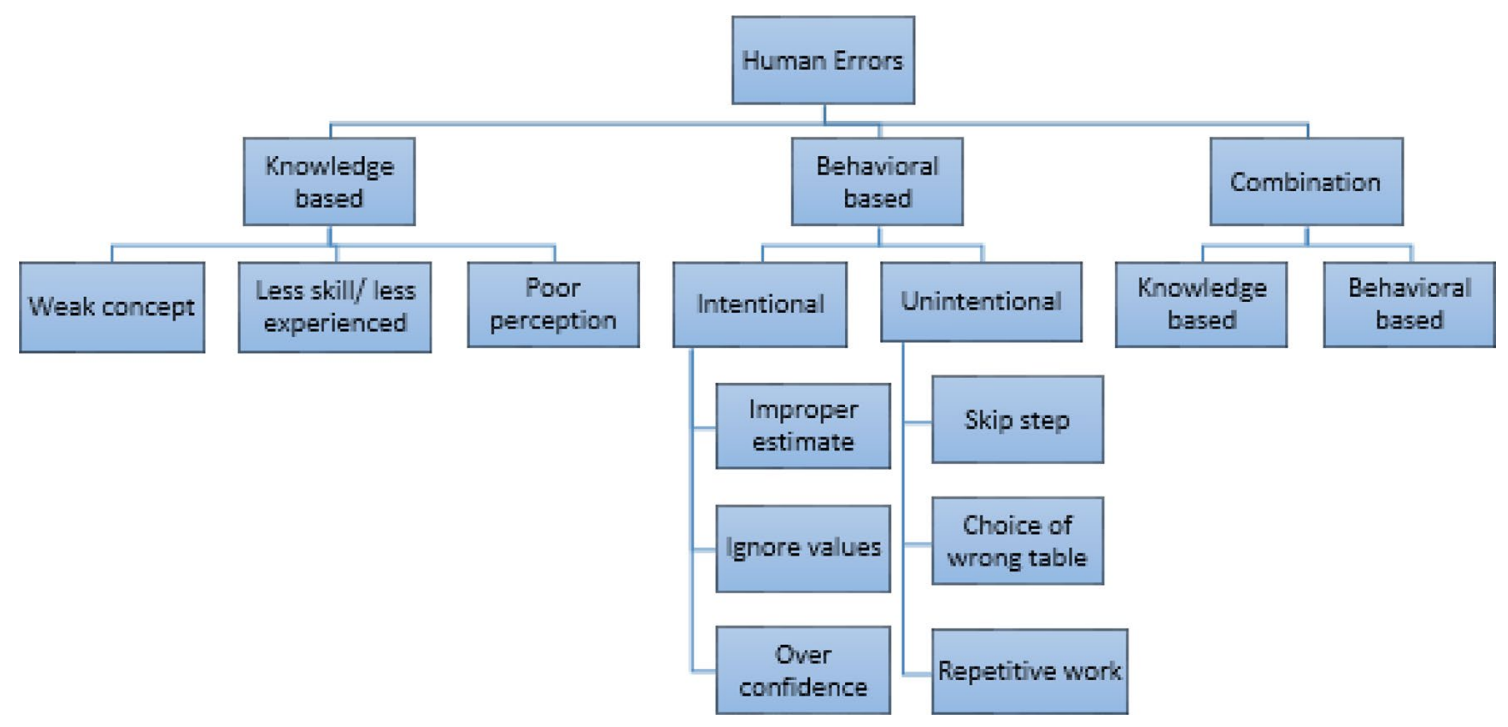

Fig. 2 Classification of human errors 
slope were the main causes of the landslide. Tariq [16] also reported that the Bukit Antarabangsa landslide was most likely due to the water leakage from active water pipes.

From eyewitness accounts, the affected bungalows were described as "floating up and down" when they were swept away by the failure debris. This clearly indicates that the debris was "very fluid" in nature, and the landslide slip plane must have been deep, well below the foundation levels of some of the houses. The debris traveling distance of approximately $214 \mathrm{~m}$ also confirms that the debris was "fluid-like" [15].

The landslide of Bukit Antarabangsa 2008 alarmed the Malaysian construction industry and prompted a review of its practices and standards. As noted above, leakage from a water pipe was a major triggering factor for this landslide, increasing the pore water pressure of the soil and resulting in slope failure. This suggests the possibility of human error, because leakages can only occur when a pipe is ruptured. The background to this landslide must, therefore, be studied to identify the causes that were ambiguous to take initiatives for the prevention of landslides in future.

\section{Objectives of the study}

The objectives of this study are:

1. to investigate and analyze the causes of the pipe burst event in the Bukit Antarabangsa 2008 landslide;

2. to identify the role of human error in the contribution of the pipe burst event;

3. to propose a theoretical framework for categorizing human errors in slope construction.

\section{Location and geology of the landslide area}

Bukit Antarabangsa is a hillside township situated in Ulu Klang, Selangor. It is geographically located at $3^{\circ} 12^{\prime} 00^{\prime \prime}$ north latitude and $101^{\circ} 46^{\prime} 01^{\prime \prime}$ east. Due to its close proximity to Kuala Lumpur, there has been a rapid increase in infrastructure development and construction projects in this area. Land types vary from the flat terrain of peat swamp forests, grassland, ex-mine sites and scrub areas to a very hilly area of natural forest $420 \mathrm{~m}$ above sea level [17]. The soil consists of $45 \%$ sand, $37.5 \%$ clay and $17.5 \%$ silt [18]. Based on the given texture, the soil type is clay loam. This is substantiated by Jebur et al. [19].

Malaysia is a tropical country. Landslides have been a basic problem in hilly areas during the monsoon seasons [20]. Although the geology of the study area is fairly stable, ongoing growth and urbanization have led to deforestation and weathering as well as erosion of the covered soil masses, leading to a severe threat to slopes [21]. For example, the disastrous landslide that occurred over the area in
1993 was due to the collapse of the Highland Tower. In this incident, the contribution of human error was found to be dominant in triggering the landslide. Other potential causes of failure included inadequacy of drainage, failure of rubble wall and rail pile foundation [22]. Later, on 6 December 2008, the study area experienced another landslide disaster only $1.4 \mathrm{~km}$ from the Highland Tower site, and the area was classified as having a high-risk potential for landslides [17]. The main land use around the study area is agricultural, particularly for coconut plantations, paddy fields and palm oil plantations. Palm oil and rubber estates have been established here through forest conversion. However, it is noted that many parts of the study area are being converted into urban, residential, recreational and industrial areas [23].

The properties of soil at the place of the landslide are given in Table 2.

Figure 3 illustrates the location of the 2008 Bukit Antarabangsa landslide. Figure 4 shows the overall view of the slope after the failure. Figure 5 portrays the location of the pipeline which runs alongside the abandoned houses, and Fig. 6 displays the location of the cross section.

The cross section shown in Fig. 6 was obtained using terrestrial laser scanning (TLS) and light detection and ranging (LIDAR) method. The ratio of the failure depth (approximately, $15 \mathrm{~m}$ ) and the slope length $(120 \mathrm{~m}$ ) was found to be greater than 0.1, and the failure can thus be classified as deep seated. Such a failure is usually governed by groundwater and/or high pore water pressure within the slope [15].

The rocks in the Ulu Klang area can be classified into two types: namely, rocks with intrusive acid and rocks with nonintrusive acid as illustrated in Fig. 7. These are the igneous rocks which are formed by the cooling of magma.

Figure 8 shows that there are four types of surface cover parameters in the landslide area, namely, thick forest, woodland (shrub), agricultural land and paved land (developed).

Site investigation data reported by Huat et al. [15] and Mariappan et al. [25] show that the slope was underlain by

Table 2 Characteristics of soil at Bukit Antarabangsa 2008 [18]

\begin{tabular}{ll}
\hline Soil characteristics & \\
Unit weight $(\gamma) \mathrm{kN} / \mathrm{m}^{3}$ & 18.50 \\
Specific gravity $\left(G_{\mathrm{s}}\right)$ & 2.65 \\
Soil texture & \\
Silt $(\%)$ & 17.50 \\
Sand $(\%)$ & 45.00 \\
Clay $(\%)$ & 37.50 \\
Shear strength parameter & \\
Friction angle $(\varphi)^{\circ}$ & 23 \\
Cohesion $(c) \mathrm{kPa}$ & 8.70 \\
Permeability $(\mathrm{m} / \mathrm{s})$ & $2.4048 \times 10^{-3}$ \\
Porosity $(\%)$ & 43.00 \\
\hline
\end{tabular}




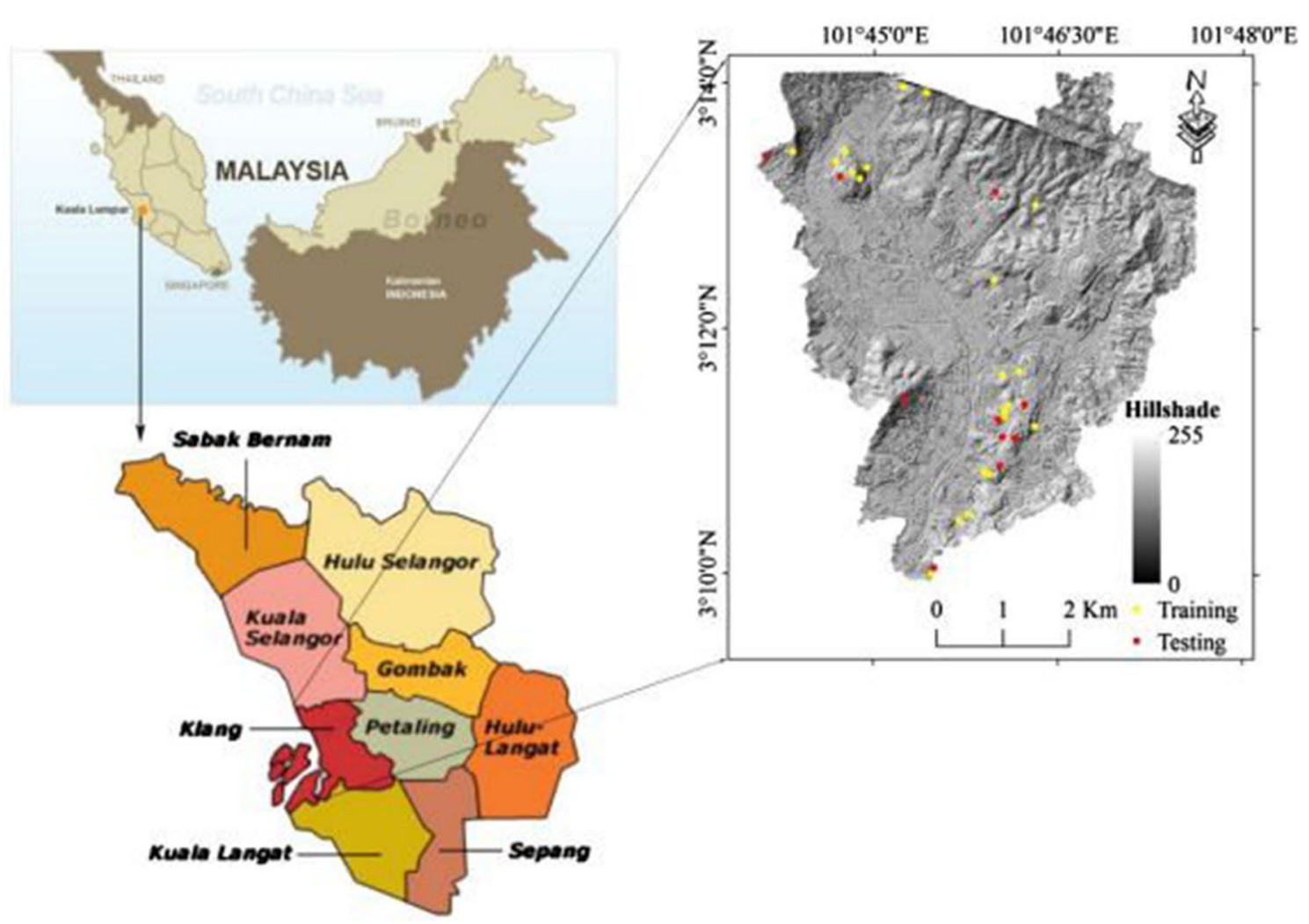

Fig. 3 Landslide location map of Bukit Antarabangsa, Ulu Klang, Malaysia [19]

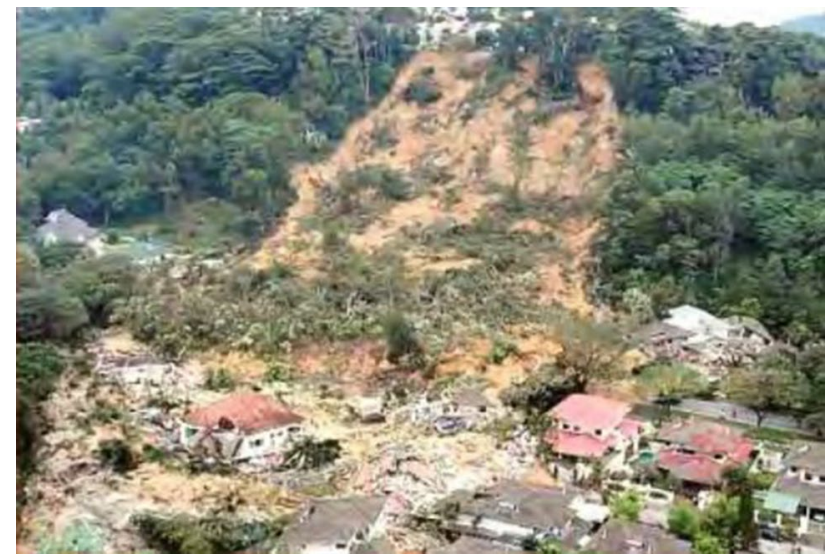

Fig. 4 Overall view of the Bukit Antarabangsa 2008 landslide [15]

three soil layers, namely silt, sandy gravel and granite. The properties of the soils are listed in Table 3. The groundwater table was detected at about $15 \mathrm{~m}$ from ground level at the crest and $1.5 \mathrm{~m}$ at the toe during dry conditions [26].

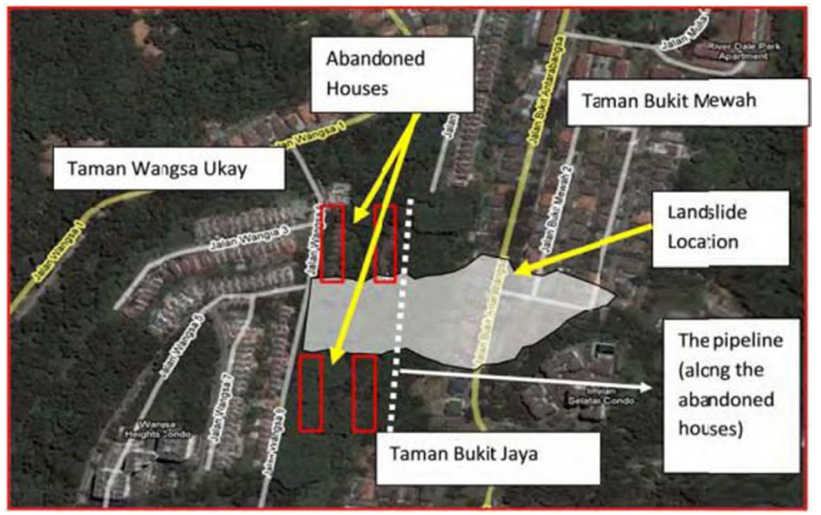

Fig. 5 Failure area of the Bukit Antarabangsa 2008 landslide. Location of pipelines [15]

\section{Water to cause damage: rainfall precipitation or pipe burst}

In the area of Ulu Klang, maximum daily precipitation data can be obtained from the results produced by the Ampang Irrigation and Drainage Department as illustrated in Table 4. There are three rain observation stations: Ukay Height Station, JPS Ampang Station and Genting Klang Station [24]. 


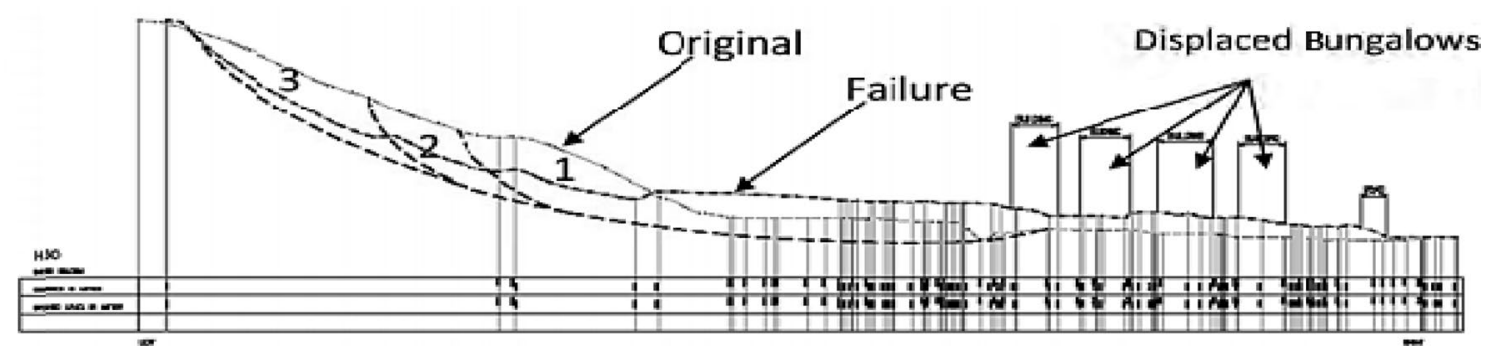

Fig. 6 Cross section extracted from TLS and LIDAR showing the three slumps [15]

Fig. 7 Type of rocks in the Ulu Klang area [24]

Fig. 8 Parameter of the surface cover [24]
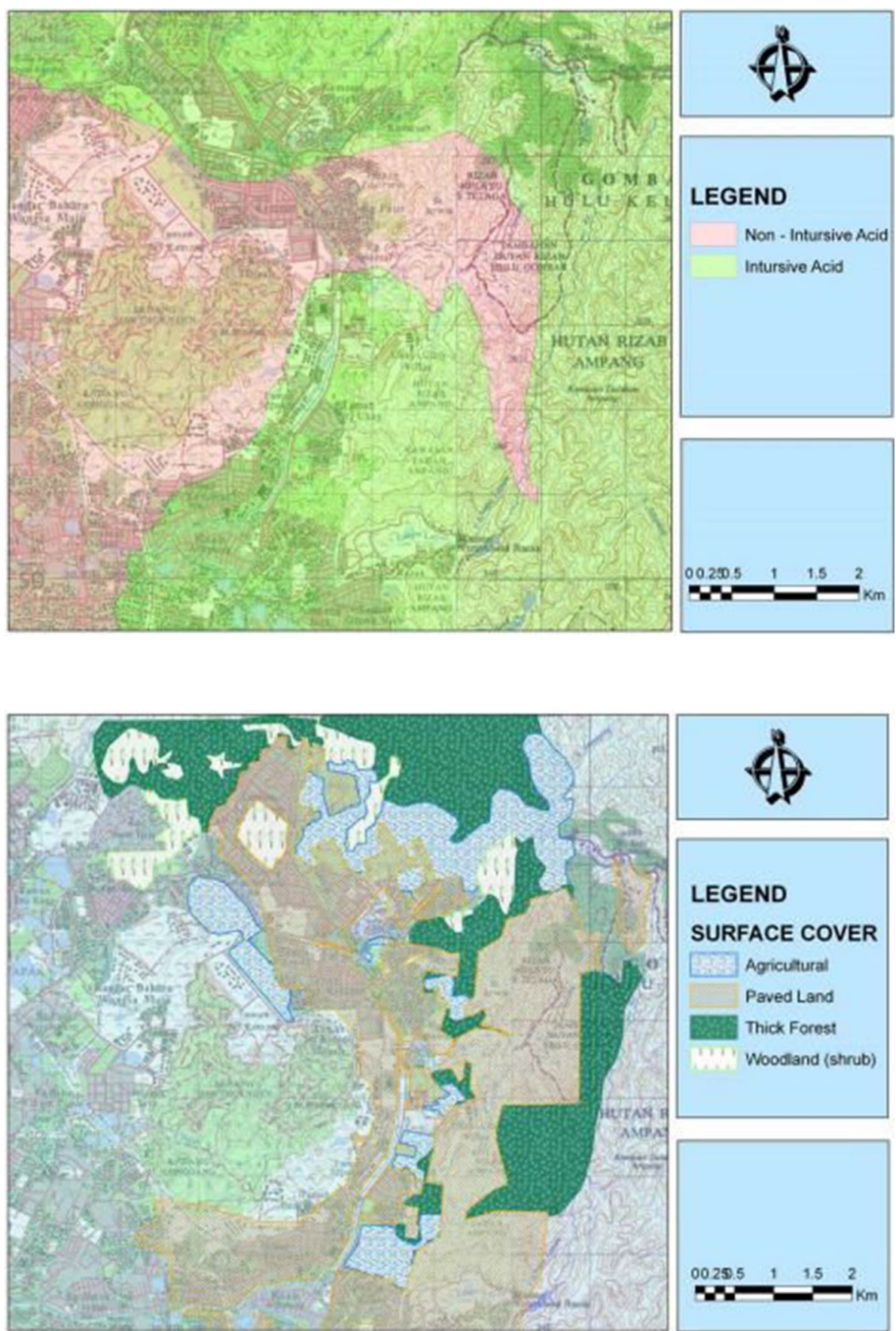
Table 3 Soil properties data of the Bukit Antarabangsa slope [26]

\begin{tabular}{llllll}
\hline Soil layer & Soil type & Depth & $\begin{array}{l}\text { Effective cohe- } \\
\text { sion } \mathrm{c}^{\prime}(\mathrm{kPa})\end{array}$ & $\begin{array}{l}\text { Effective friction } \\
\text { angle } \varphi^{\prime}\left(^{\circ}\right)\end{array}$ & $\begin{array}{l}\text { Soil unit } \\
\text { weight } \gamma^{\prime} \\
(\mathrm{kPa})\end{array}$ \\
\hline Layer 1 & Silt & $0-13.5 \mathrm{~m}$ & 3 & 26 & 17.5 \\
Layer 2 & Sandy gravel & $13.5-17 \mathrm{~m}$ & 8 & 32 & 18 \\
Layer 3 & Granite & 17 m onward & 10 & 38 & 18.5 \\
\hline
\end{tabular}

Table 4 Maximum daily precipitation data [24]

\begin{tabular}{lrrrrrr}
\hline & \multicolumn{7}{c}{ Maximum daily precipitation $(\mathrm{mm})$} & & \\
\cline { 2 - 7 } & 2004 & 2005 & 2006 & 2007 & 2008 & Average \\
\hline Genting Klang station & 105.5 & 101.0 & 145.0 & 138.5 & 98.5 & 117.7 \\
JPS Ampang station & 75.0 & 102.0 & 116.5 & 96.5 & 107.5 & 99.5 \\
Ukay height station & 98.0 & 100.0 & 83.0 & 98.0 & 119 & 99.6 \\
\hline
\end{tabular}

continuous soil saturation at the lower slope and this, in turn,

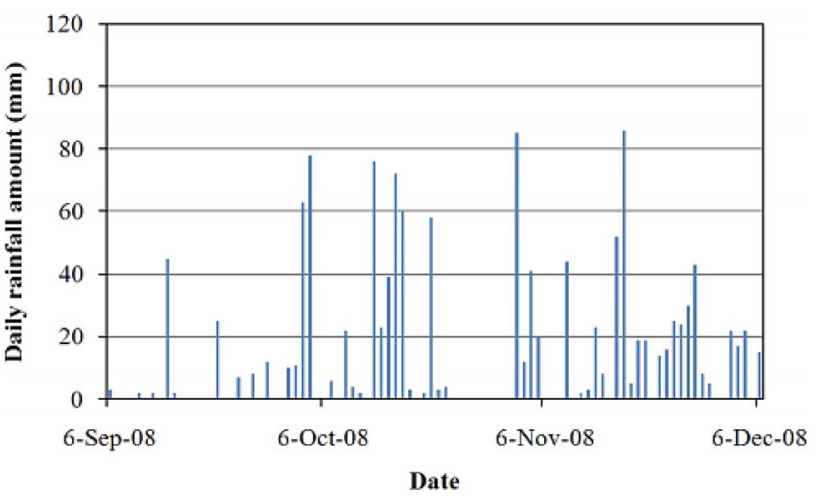
accelerated the soil creep [15].

\section{Methodology}

Fault tree analysis (FTA) is a logical and diagrammatic method to evaluate the probability of an accident resulting from sequences and combinations of faults and failure events. The conventional FTA, based on a probabilistic approach, has been used extensively in the past. However, it is often very difficult to estimate the precise failure rates or failure probabilities of individual components or failure events. This happens particularly in systems like nuclear power plants, where available data are insufficient for statistical inferences or the data show a large variation [28].

This study used the FTA technique to evaluate the pipe burst event at the 2008 Bukit Antarabangsa landslide by tracing the contributors of the event. The reason for applying FTA is that it uses logics and Boolean algebra to identify events that are responsible for causing undesired events. It is a top-down technique in which primary events are placed at the end and the outcome rests at the top level. The analysis is performed with the help of OR and AND gates. Using the Boolean algebra basics, AND gates are replaced with the product of the assigned values and OR gates by the sum of their input. Probabilities are assigned to the lowest events to estimate the top event's probability.

Table 5 provides an account of the types of events for the FTA, including their category, symbol and description.

The sequence of contributing events in the pipe burst was assessed by applying FTA. The probabilities were assigned by adopting a similar approach to that used by Duncan [29]. The subjective probability of events was determined by conducting survey research by the experts of the slope engineering division of the JKR department in Malaysia. 
Table 5 Fault tree analysis symbols and descriptions

\begin{tabular}{l} 
Category \\
\hline Basic event
\end{tabular}

The first step in quantifying a fault tree is to assign the initial probabilities to the basic events. This step is performed by collecting information from a designated group which is cognizant of the particular situations. The group is given the graphical fault tree and then asked to give the probability of basic events using their knowledge and experience. A properly developed fault tree addresses the sequence of a failure and provides the qualitative and quantitative evaluation of an event [30].

The qualitative construction of the fault tree reflects the relation between the events. It does not, conversely, represent the amount of influence the basic events have on the top fault event. A quantified fault tree illustrates the influence of a basic event on the top fault event and ranks the basic events in terms of this influence. The expediency of a fault tree approach becomes evident in such a construction. A quantified fault tree is a tactic and it shows the influence of events on the occurrence of the top fault event. It highlights the events that should be dealt first in any type of proficient and useful curative action [30].

\section{Results}

The subjective probabilities were ascertained by experts in the JKR slope engineering division by doing survey research using interview-administered questionnaire on the potential landslide events. This process tried to capture those factors that were potentially responsible for the pipe burst. The process of snowball sampling was used to gather experts; subjects were asked to nominate another person within the same field, and the process works like a chain referral. This study selected 25 experts on the basis of their expertise in geotechnical engineering and slope construction. The research followed the aggregated individual method and consensus group method to use the experts' opinions and to obtain independent and precise data.

The basic events and their corresponding subjective probabilities are given in Table 6. The FTA of the pipe burst event at the Bukit Antarabangsa landslide in 2008 is illustrated in Fig. 10.

\section{Discussion}

The technique of FTA provides a route for tracing the contributors of an event. Previously, it was also used in the analysis of urban flooding by Ten Veldhuis et al. [31]. In case of the Bukit Antarabangsa 2008 landslide, the possibility of a pipe burst could have been successfully tackled by paying attention to maintenance. The FTA of the pipe burst shows that the subjective probability of "high acidity levels in the water" is 0.278 , which is the highest among the probabilities of other basic events. The acidity level of the water played a significant role in corroding the pipes internally. In a limited context, the water velocity was also noted, but its potential was almost negligible in this case. In the context of a fatigue event, constant pressure and cyclic pressure can be the two potential causes. Failure due to constant water pressure is the outcome of improper design, which gave the second highest subjective probability.

One basic event of third party excavation was also involved, but according to the results the probability of this event playing a role in the landslide was around 10E-4. External loading, another potential threat, was estimated by classifying it into land use and temporary extra surcharge load and their subjective probabilities were found to be 0.01 and 0.092 , respectively. Similar events have also been 
Table 6 Pipe burst event (PBE) logic of Bukit Antarabangsa 2008

\begin{tabular}{|c|c|c|c|c|c|}
\hline & Basic events & $\begin{array}{l}\text { Subjective } \\
\text { probabilities }\end{array}$ & & Basic events & $\begin{array}{l}\text { Subjective prob- } \\
\text { abilities }\end{array}$ \\
\hline TPE & Third party excavation & 0.0001 & ID & Improper design & 0.143 \\
\hline $\mathrm{LU}$ & Land use & 0.01 & DF & Debris flow & 0.048 \\
\hline TES & Temporary extra surcharge load & 0.092 & TR & Tree roots & 0.001 \\
\hline IE & Internal erosion & 0.001 & $\mathrm{PH}$ & High acidity levels in the water & 0.278 \\
\hline SOG & Settling of ground & 0.001 & VOW & Velocity of water & 0.0001 \\
\hline MD & Material defect & 0.00001 & SM & Soil moisture & 0.001 \\
\hline WH & Water hammer & 0.0001 & OSC & Other soil characteristics & 0.139 \\
\hline SCC & Sudden climatic change & 0.000001 & & & \\
\hline \multicolumn{6}{|c|}{ Top event } \\
\hline PBE & & & Pipe burst event & & \\
\hline \multicolumn{6}{|c|}{ Intermediate events } \\
\hline $\mathrm{CR}$ & & & Cracking & & \\
\hline EXL & & & External loading & & \\
\hline $\mathrm{DF}$ & & & Deformation & & \\
\hline WT & & & Wall thinning & & \\
\hline FA & & & Fatigue & & \\
\hline $\mathrm{CP}$ & & & Constant Pressure & & \\
\hline CYP & & & Cyclic pressure & & \\
\hline $\mathrm{BL}$ & & & Blocked drains & & \\
\hline $\mathrm{CO}$ & & & Internal corrosion & & \\
\hline IN & & & Corrosion & & \\
\hline EX & & & External corrosion & & \\
\hline
\end{tabular}

Fig. 10 Fault tree logic of the pipe burst event of Bukit Antarabangsa 2008

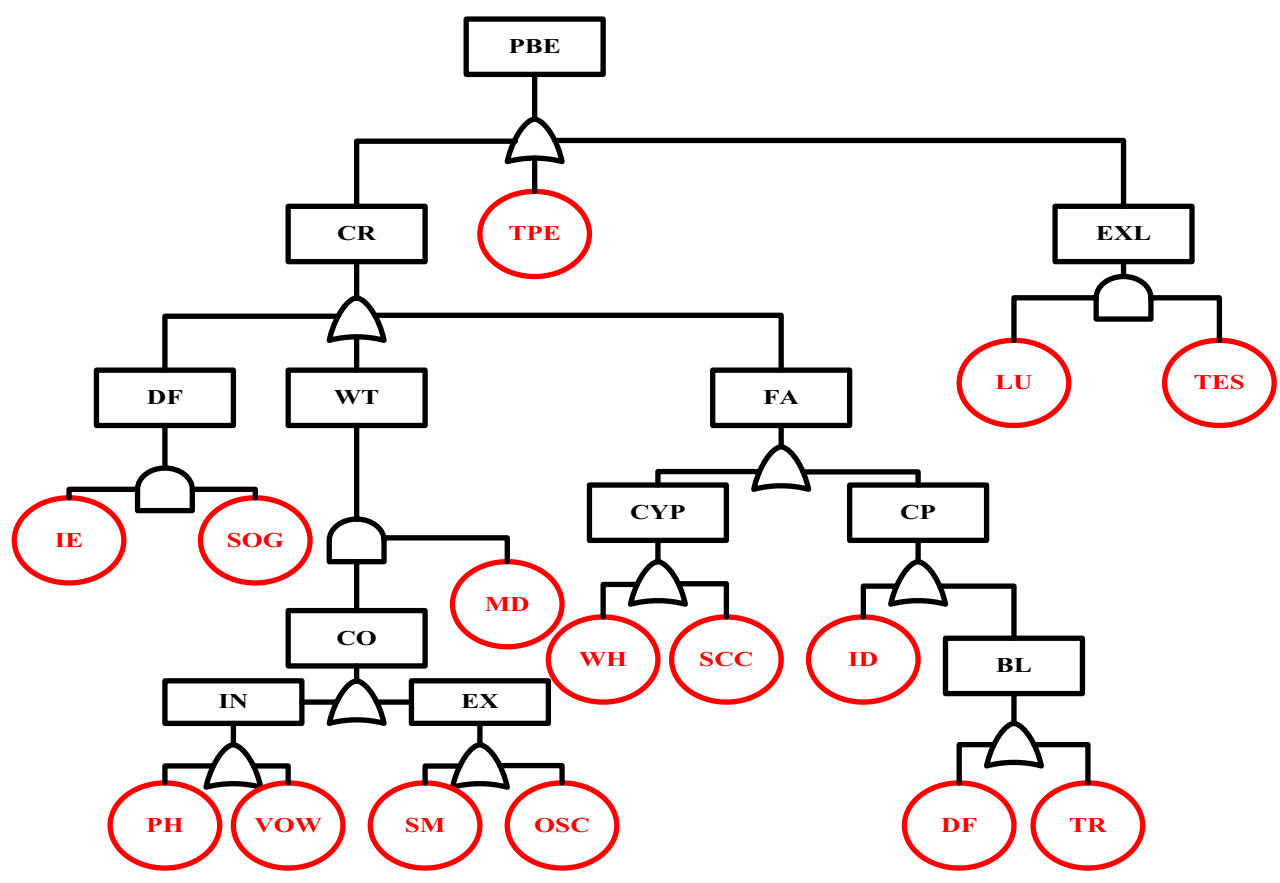

observed by Mariappan [25] and Jaboyedoff et al. [32]. The contributing events of land use and temporary extra surcharge load can be easily overcome by routine monitoring as compared to other non-maintenance issues.
In this context, Monteleone and Sabatino [33] concluded that any human activity can alter the rhythm and sequence of events in the surrounding environment and that these changes are most often irreversible. Hence, it is imperative 


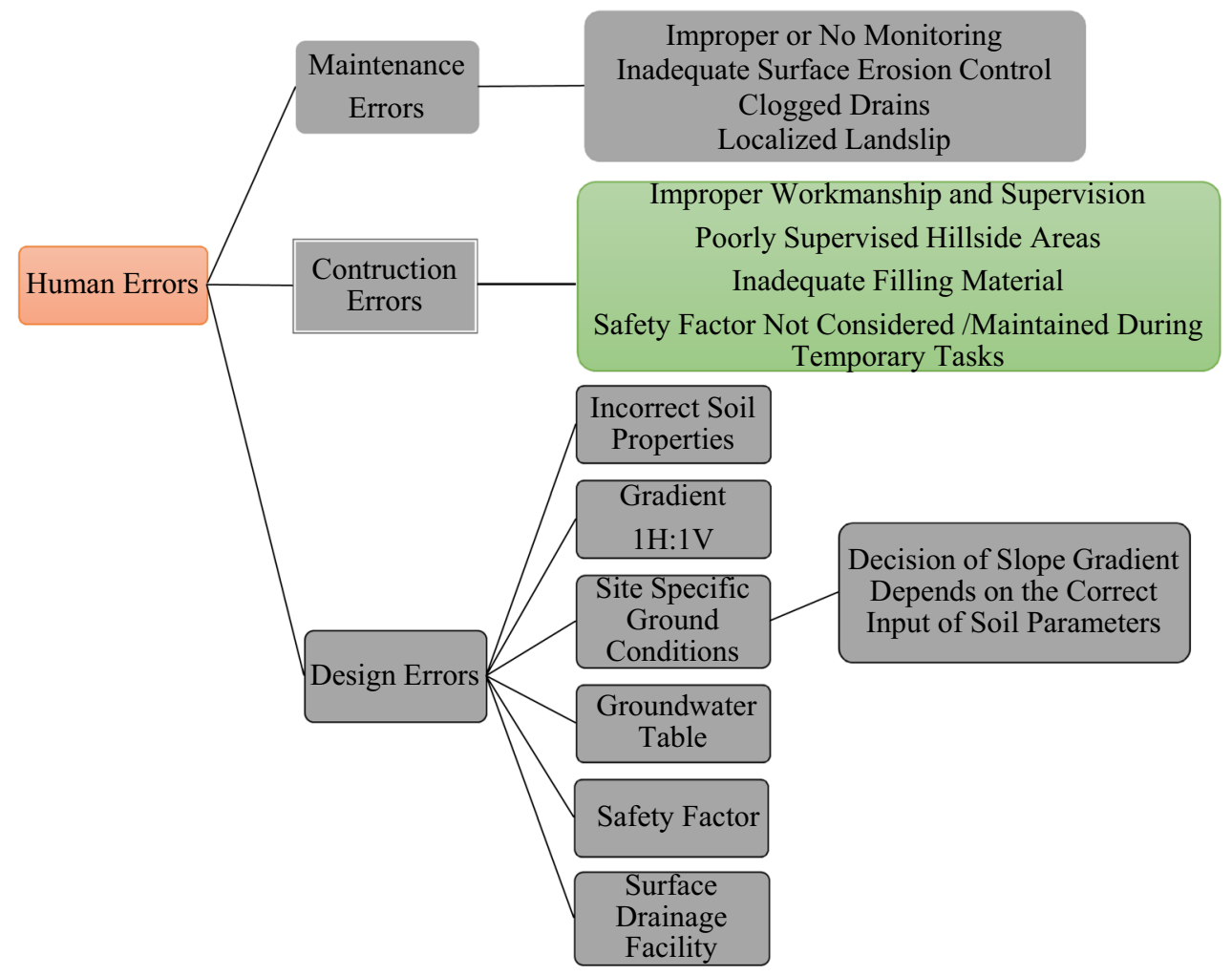

Fig. 11 Theoretical framework to categorize human errors in slope construction

to plan land uses on the basis of geological and morphological considerations, rather than administrative ones. Further, the local communities should be made aware of geo-environmental hazards to prevent several types of losses.

Considering the mechanism of landslide activation, the Bukit Antarabangsa 2008 landslide was triggered by the bursting of an active water pipe alongside abandoned houses. Based on the results of FTA, it is clear that factors such as high acidity levels in the water (leading to the corrosion of the pipe), improper design and a temporary extra surcharge load were the major factors contributing to the rupture of the water pipe. The heavy discharge of water saturated the soil by increasing its pore water pressure, which ultimately reduced its strength to support the surcharge load, leading to the slope failure.

Figure 11 demonstrates that human errors are mainly categorized into design, construction and maintenance errors in terms of slope construction. The human errors occurring in the design phase of slope construction include the selection of incorrect soil properties, disregarding the site-specific ground conditions such as an investigation of groundwater table and neglecting the guidelines about required safety factor coupled with an inadequate layout of the drainage system. In the construction phase, most of the human errors are linked to the improper workmanship and noncompliance with the protocols leading to the poor implementation of design. The human errors governing the maintenance phase are related to the improper monitoring of the slope, which includes inattention to repairs, inadequate measures to control surface erosion and inefficient drainage system due to clogged drains.

\section{Conclusion}

This study concludes that the Bukit Antarabangsa landslide of 6 December 2008 occurred as a consequence of the bursting of an active water pipe, which increased the pore water pressure of the soil and eventually reduced the ability of the slope to sustain the surcharge load. In this study, FTA revealed that the main causes of the pipe burst that triggered the landslide were human based. According to the analysis, the major flaws leading to pipe burst were high acidity levels in the water, improper design and temporary extra surcharge load, all of which were related to human error. Further, maintenance issues including improper land use were noted. Therefore, this study concludes that the causes of the Bukit Antarabangsa 2008 landslide were mainly human 
based, which in essence is in agreement with previous studies on other landslides in Malaysia.

\section{References}

1. Matori AN, Basith A, Harahap ISH (2012) Study of regional monsoonal effects on landslide hazard zonation in Cameron Highlands, Malaysia. Arab J Geosci 5(5):1069-1084

2. Nanak W, Harahap I (2012) Framework of human reliability analysis in a geotechnical risk assessment for hillside development. WIT Trans Eng Sci 73:219-230

3. Qasim S, Harahap I, Osman S, Baharom S (2013) Causal factors of Malaysian landslides: a narrative study. Res J Appl Sci Eng Technol 5(7):2303-2308

4. Harahap I, Aini F (2010) On aspects of geotechnical risk assessment for hillside development. International conference on sustainable building and infrastructure (ICSBI2010) Kuala Lumpur, Malaysia

5. Røstum J (2000) Statistical modelling of pipe failures in water networks. Doctoral dissertation, Norwegian University of Science and Technology, Trondheim, Norway

6. See-Sew G, Tan YC (2006) Landslides: abuses of the prescriptive method. International conference on slope 2006, Kuala Lumpur, Malaysia, 7-8 Aug 2006

7. JKR (2009) National slope master plan. Sectoral report research and development, vol. Jabatan Kerja Raya Malaysia

8. Peck RB (1969) Advantages and limitations of the observational method in applied soil mechanics. Geotechnique 19(2):171-187

9. Nadim F (2007) Tools and strategies for dealing with uncertainty in geotechnics. Probab Methods Geotech Eng 491:71-95

10. Whitman RV (2000) Organizing and evaluating uncertainty in geotechnical engineering. J Geotech Geoenviron Eng 126(7):583-593

11. Sowers GF (1993) Human factors in civil and geotechnical engineering failures. J Geotech Eng 119(2):238-256

12. Bea R (2006) Reliability and human factors in geotechnical engineering. J Geotech Geoenviron Eng 132(5):631-643

13. Kazmi D, Qasim S, Harahap I, Baharom S, Imran M, Moin S (2017) A study on the contributing factors of major landslides in Malaysia. Civil Eng J 2(12):669-678

14. Kazmi D, Qasim S, Harahap I, Baharom S, Mehmood M, Siddiqui FI, Imran M (2017) Slope remediation techniques and overview of landslide risk management. Civil Eng J 3(3):180-189

15. Huat LT, Ali F, Ibrahim AS (2012) An investigation on one of the rainfall-induced landslides in Malaysia. Electron J Geotech Eng 17:435-449

16. Tariq Q (2013) Engineer tells court the 2008 Bkt Antarabangsa landslide likely caused by water pipe leaks. Available from: http:// www.thestar.com.my/news/nation/2013/04/08/engineer-tellscourt-the-2008-bkt-antarabangsa-landslide-likely-caused-bywater-pipe-leaks/. Accessed 15 Feb 2017

17. Hassaballa AA, Althuwaynee OF, Pradhan B (2014) Extraction of soil moisture from RADARSAT-1 and its role in the formation of the 6 Dec 2008 landslide at Bukit Antarabangsa, Kuala Lumpur. Arab J Geosci 7(7):2831-2840

18. Mukhlisin M, Idris I, Yaacob WZW, ElShafie A, Taha MR (2011) Soil slope deformation behavior in relation to soil water interaction based on centrifuge physical modeling. Int J Phys Sci 6(13):3126-3133

19. Jebur MN, Pradhan B, Tehrany MS (2014) Optimization of landslide conditioning factors using very high-resolution airborne laser scanning (LiDAR) data at catchment scale. Remote Sens Environ 152:150-165

20. Sharma L, Patel N, Debnath P, Ghose M (2012) Assessing landslide vulnerability from soil characteristics-a GIS-based analysis. Arab J Geosci 5(4):789-796

21. Lee S, Pradhan B (2007) Landslide hazard mapping at Selangor, Malaysia using frequency ratio and logistic regression models. Landslides 4(1):33-41

22. Kazmi D, Qasim S, Harahap I, Baharom S (2017) Landslide of highland towers 1993: a case study of Malaysia. Innov Infrastruct Solut 2(1):21

23. Althuwaynee OF, Pradhan B, Lee S (2012) Application of an evidential belief function model in landslide susceptibility mapping. Comput Geosci 44:120-135

24. Mukhlisin M, Idris I, Salazar AS, Nizam K, Taha MR (2010) GIS based landslide hazard mapping prediction in Ulu Klang, Malaysia. J Math Fundam Sci 42(2):163-178

25. Mariappan S, Ashaari M, Low T, Nik Ramlan N, Chong S, Subramaniam S (2011) Remedial measures adopted for slope failure at Bukit Antarabangsa, Malaysia. Enecal Consultants Sdn Bhd, Jabatan Kerja Raya, Mohd Asbi \& Associates, Kuala Lumpur

26. Ng KY (2012) Rainfall-induced landslides in Hulu Kelang area, Malaysia. UTAR, Petaling Jaya

27. Fatt C, Fong Y (2009) Study of the rainfall characteristics of Bukit Antarabangsa area in relation to the landslide incident on 6th Dec 2008. 11th Annual IEM Water Resources Colloquium 2009

28. Jackson P, Hockenbury R, Yeater M (1982) Uncertainty analysis of system reliability and availability assessment. Nucl Eng Des 68(1):5-29

29. Duncan JM (2000) Factors of safety and reliability in geotechnical engineering. J Geotech Geoenviron Eng 126(4):307-316

30. Vesely WE, Goldberg FF, Roberts NH, Haasl DF (1981) Fault tree handbook. Nuclear Regulatory Commission, Washington

31. Ten Veldhuis J, Clemens F, Van Gelder P (2009) Fault tree analysis for urban flooding. Water Sci Technol 59(8):1621-1629

32. Jaboyedoff M, Michoud C, Derron M, Voumard J, Leibundgut G, Sudmeier-Rieux K, Nadim F, Leroi E (2016) Human-induced landslides: toward the analysis of anthropogenic changes of the slope environment. Landslides and engineered slopes. Experience, theory and practice: Proceedings of the 12th International Symposium on Landslides (Napoli). CRC Press, Boca Raton

33. Monteleone S, Sabatino M (2014) Hydrogeological hazards and weather events: triggering and evolution of shallow landslides. Int Soil Water Conserv Res 2(2):23-29 